\title{
Research on Evaluation Technology of Lock Chamber Wall
}

\author{
Fangshu Qian ${ }^{1, a}$, Titao Wang ${ }^{1, b}$, Hongwei Ding ${ }^{1, c}$, Xiaojun Chen ${ }^{1, d}$ \\ 1. No.1 Xikang Road, College of Harbour, Coastal and Offshore Engineering, Hohai University, \\ 210098, Nanjing CHINA \\ a1551212677@qq.com, b1124902375@qq.com, c2565530962@qq.com,d913266877@qq.com
}

Keywords: Lock chamber walls; Evaluation technology; Indicators

Abstract. Under the influence of natural and human factors, most hydraulic structures will be damaged. Therefore, an index parameter system is proposed to reflect the surface integrity of lock chamber wall, durability and strength, etc. Meanwhile, the corresponding testing technology and testing methods for the use of all necessary indicators are made. On the basis of this, researches of evaluation technology are carried out to determine whether the wall surface needs to be repaired. According to the processing requirements and regulations to repair and reinforce it.

\section{Introduction}

After years of operation under the influence of natural and human factors, the structure, materials function of most of locks and other hydraulic structures vary degrees of damage. Phenomena of concrete aging and severely damaged, concrete surface cracking, erosion and water seepage are more common.

There are more than 100 navigation locks in Jiangsu, many of which are built 50 years ago or built in the 1980's, mostly designed in low standard and having serious aging damage. What's more, with the increase in size and frequency of operation of the ship, the lock chamber wall suffered severe wear and serious cracking.

At present, the detection and grade assessment of lock chamber are mainly based on "Technical Specification for Detection and Assessment of Harbour and Marine Structures"(JTJ302-2006) and "Safety Identification Regulations of Locks"(SL214-98) ${ }^{[1]}$, lacking the specification for inspection and evaluation of lock chamber. Jiazheng Li believed that the positive evaluation of the locks should start with overall reliability and evaluate the structure and operation of the various structural components respectively ${ }^{[2]}$. Hangzhou Wang proposed lock buildings and structures reliability assessment based primarily on national and sectoral peremptory norms and carry out from the three aspects of safety, durability and serviceability requirements ${ }^{[3]}$.

In addition, the evaluation methods of concrete structure are mainly divided into two categories ${ }^{[4-7]}$. The first kind of evaluation methods analyses the internal stress and deformation theory of the structure, studies the mechanical, physical and chemical of the damage, so as to determine whether the structure to reach the ultimate bearing capacity. The second kind of evaluation methods analyses the inspection data of engineering and structural components, studys on the reason of the structure damage, establishes index system and judges the aging degree of structure.

Therefore, it is necessary to propose the index system parameters which can reflect the wall surface integrity, durability and strength with modern testing techniques and analysis methods. So that the research on evaluation technology can be carried out on the basic of this to provide a basis for judging and evaluating whether the lock chamber wall needs to be repaired. And according to the technology, we are able to treat the damaged lock chamber wall structure to restore the function of use and improve the overall reliability of the navigation locks.

In summary, the researches on the detection and evaluation of lock chamber, especially the lock chamber wall are rare. This paper reasonably selects the critical indicators of detection and evaluation by using the reliability of the lock chamber wall as the overall goal and combining the structural characteristics and operational environment of it. According to relevant documents to make research on evaluation technology and on the basis of the processing requirements to repair and reinforce it. 


\section{Selection of Detection and Evaluation Indicators}

The lock chamber walls are usually reinforced concrete structure. Current detection of reinforced concrete structures typically includes visual inspection, crack inspection, measuring the depth of concrete carbonation, chloride content analysis, internal defect inspection of concrete and concrete strength evaluation, as well as reinforced protective layer thickness inspection, steel corrosion rate analysis. Under normal conditions of use, the durability of concrete is closely related to environment and concrete quality. Lock chambers are vulnerable to the impact of ships and water erosion. Phenomena of wear, erosion and cracking are more common. Thus, according to the lock chamber wall structure characteristics and the environment, reasonably determining the critical detection and evaluation indicators is an important part of the study.

We took the defects of appearance, concrete strength and durability as the index to evaluate. The defects of appearance includes surface cracks, peeling, deteriorated appearance due to steel corrosion and wear. The concrete strength of chamber wall surface includes concrete compressive strength, tensile strength and shear strength. The durability of chamber wall includes concrete internal defects, carbonation depth, thickness of concrete cover and extent of steel corrosion.

\section{Research on Evaluation Methodology Lock Chamber Wall}

The result of testing will be divided into A,B,C and D four levels (Table 1) in reference to "Safety Identification Regulations of Locks"(SL214-98), "Technical Specification for Detection and Assessment of Harbour and Marine Structures"(JTJ302-2006), "Control Standards of Concrete Quality in Waterway"(JTS202-2-2011), other existing norms and related articles. Then requirements for the processing of repair and reinforcement can be done by relevant specification (Table 2).

Table 1. Grade estimation for lock chamber wall testing project

\begin{tabular}{|c|c|c|c|c|c|}
\hline \multirow{2}{*}{\multicolumn{2}{|c|}{ Test items }} & \multicolumn{4}{|c|}{ Grade } \\
\hline & & A & B & $\mathrm{C}$ & $\mathrm{D}$ \\
\hline \multirow{2}{*}{$\begin{array}{l}\text { The defects of } \\
\text { appearance }\end{array}$} & Surface cracks & No cracks & $\begin{array}{c}\text { The local has } \\
\text { slight } \\
\text { corrosion } \\
\text { cracks. Crack } \\
\text { width is less } \\
\text { than } 0.3[\mathrm{~mm}]\end{array}$ & $\begin{array}{c}\text { More } \\
\text { corrosion } \\
\text { cracks or } \\
\text { reticular } \\
\text { cracks. Crack } \\
\text { width is } \\
\text { between } \\
0.3[\mathrm{~mm}] \text { to } \\
1.0[\mathrm{~mm}]\end{array}$ & $\begin{array}{l}\text { A large area of } \\
\text { corrosion } \\
\text { cracks, which } \\
\text { take on net } \\
\text { structure. } \\
\text { Crack width is } \\
\text { greater than } \\
1.0[\mathrm{~mm}]\end{array}$ \\
\hline & Peeling & No peeling & $\begin{array}{c}\text { Locally } \\
\text { hollowing in } \\
\text { small area }\end{array}$ & $\begin{array}{l}\text { Locally } \\
\text { peeling. The } \\
\text { area of flaking } \\
\text { and hollowing } \\
\text { is less than } \\
30 \% \text { of area of } \\
\text { zone }\end{array}$ & $\begin{array}{l}\text { A large area of } \\
\text { peeling. The } \\
\text { area of flaking } \\
\text { and hollowing } \\
\text { is more than } \\
30 \% \text { of area of } \\
\text { zone }\end{array}$ \\
\hline
\end{tabular}




\begin{tabular}{|c|c|c|c|c|c|}
\hline & $\begin{array}{l}\text { Deteriorated } \\
\text { appearance } \\
\text { due to steel } \\
\text { corrosion }\end{array}$ & $\begin{array}{c}\text { No } \\
\text { deterioration }\end{array}$ & $\begin{array}{l}\text { Local rust on } \\
\text { concrete } \\
\text { surface }\end{array}$ & $\begin{array}{l}\text { More rut. The } \\
\text { range of steel } \\
\text { corrosion is } \\
\text { wide }\end{array}$ & $\begin{array}{l}\text { Universal rut, } \\
\text { most or all of } \\
\text { the steel } \\
\text { surface } \\
\text { corroded. The } \\
\text { cross-sectional } \\
\text { area of the } \\
\text { steel is } \\
\text { reduced }\end{array}$ \\
\hline & Wear & No wear & $\begin{array}{l}\text { Slight surface } \\
\text { wear }\end{array}$ & $\begin{array}{c}\text { Abrasion } \\
\text { depth is } 1 \sim 2 \\
{[\mathrm{~mm}]}\end{array}$ & $\begin{array}{l}\text { Abrasion } \\
\text { depth is } 2 \sim 3 \\
{[\mathrm{~mm}]}\end{array}$ \\
\hline $\begin{array}{l}\text { Concrete } \\
\text { strength }\end{array}$ & \multicolumn{5}{|c|}{$\begin{array}{l}\text { When the concrete strength is less than } \mathrm{C} 25 \text {, repair and reinforcement are needed. } \\
\text { Concrete compressive strength should be greater than } 45.1[\mathrm{MPa}] \text { after repair. Tensile } \\
\text { strength should be greater than } 4.08[\mathrm{MPa}] \text { and the shear strength should be greater } \\
\text { than } 15.2[\mathrm{MPa}]\end{array}$} \\
\hline \multirow{4}{*}{ Durability } & $\begin{array}{l}\text { Concrete } \\
\text { internal } \\
\text { defects }\end{array}$ & $\begin{array}{l}\text { The inner parts } \\
\text { of concrete are } \\
\text { complete and } \\
\text { uniform }\end{array}$ & $\begin{array}{l}\text { Small cracks } \\
\text { inside the } \\
\text { concrete, a } \\
\text { little } \\
\text { unevenness }\end{array}$ & $\begin{array}{l}\text { Large cracks } \\
\text { inside the } \\
\text { concrete, the } \\
\text { phenomenon } \\
\text { of Honeycomb }\end{array}$ & $\begin{array}{l}\text { Internal } \\
\text { concrete } \\
\text { crushing. The } \\
\text { phenomenon } \\
\text { of Honeycomb } \\
\text { is relatively } \\
\text { common. } \\
\text { There are } \\
\text { some voids }\end{array}$ \\
\hline & $\begin{array}{c}\text { Carbonation } \\
\text { depth }[\mathrm{mm}]\end{array}$ & $<0.7$ & $0.7 \sim 1.2$ & $1.2 \sim 1.5$ & $>1.5$ \\
\hline & $\begin{array}{l}\text { Thickness of } \\
\text { concrete cover }\end{array}$ & \multicolumn{4}{|c|}{$\begin{array}{l}\text { Concrete cover thickness of chamber wall above water, in water } \\
\text { level fluctuation zone and in underwater zone should be } \\
\text { respectively greater than } 40 \mathrm{~mm}, 40 \mathrm{~mm} \text { and } 35 \mathrm{~mm}\end{array}$} \\
\hline & $\begin{array}{c}\text { Extent of steel } \\
\text { corrosion }\end{array}$ & $\begin{array}{c}\text { Electric } \\
\text { potential is } \\
\text { greater than } \\
-150[\mathrm{mV}] \text {. } \\
\text { Slightly } \\
\text { corroded steel, } \\
\text { corrosion pits } \\
\text { or local } \\
\text { corrosion }\end{array}$ & $\begin{array}{c}\text { Electric } \\
\text { potential is } \\
\text { between }-150 \\
\sim-220[\mathrm{mV}] . \\
\text { Slightly } \\
\text { corroded steel, } \\
\text { corrosion pits } \\
\text { or local } \\
\text { corrosion }\end{array}$ & $\begin{array}{c}\text { Electric } \\
\text { potential is } \\
\text { between }-220 \\
\sim 350[\mathrm{mV}] . \\
\text { Comprehensiv } \\
\text { e steel } \\
\text { corrosion }\end{array}$ & $\begin{array}{c}\text { Electric } \\
\text { potential is less } \\
\text { than } \\
-350[\mathrm{mV}] . \\
\text { severely steel } \\
\text { corrosion }\end{array}$ \\
\hline
\end{tabular}

According to the indicators above for the lock chamber wall, the test results can be obtained on the basis of Table 2 . 
Table 2. Structure evaluation classification and processing requirements for lock chamber wall

\begin{tabular}{|c|l|c|}
\hline Grade & \multicolumn{1}{|c|}{ The classification standard } & Processing requirements \\
\hline A & $\begin{array}{l}\text { The deterioration degree conforms to grade A standard } \\
\text { requirement. The durability meets the requirements of design } \\
\text { life. }\end{array}$ & Do not take measures \\
\hline B & $\begin{array}{l}\text { The deterioration degree conforms to grade B standard } \\
\text { requirement. The durability fails to meet the requirements of } \\
\text { design life. The structural damage has not affected the carrying } \\
\text { capacity. }\end{array}$ & $\begin{array}{c}\text { Repair measures in a } \\
\text { timely manner }\end{array}$ \\
\hline C & $\begin{array}{l}\text { The deterioration degree conforms to grade C standard } \\
\text { requirement. The durability fails to meet the requirements of } \\
\text { design life. The structural damage has affected the carrying } \\
\text { capacity. }\end{array}$ & $\begin{array}{c}\text { Take immediate repair } \\
\text { and reinforcement } \\
\text { measures }\end{array}$ \\
\hline D & $\begin{array}{l}\text { The deterioration degree conforms to grade D standard } \\
\text { requirement. The durability fails to meet the requirements of } \\
\text { design life. The structural damage is severe. }\end{array}$ & $\begin{array}{l}\text { Repair and reinforcement } \\
\text { measures depending on } \\
\text { the condition or scrapped }\end{array}$ \\
\hline
\end{tabular}

\section{Conclusions}

In this paper, taking the defects of appearance, concrete strength and durability as the indicators to evaluate, according to the criterion of evaluation and processing, provides the judgement and evaluation basis for the lock chamber wall. The evaluation technology has a strong operability for the evaluation for the lock chamber wall.

\section{References}

[1] Zhou Jian. The research of detection, evaluation \& protection technology on the lock and hydraulic structures[J]. Water conservancy science and technology and economy, 2012, 18(1):46-48.

[2] Li Jiazheng, Wang Zhonghua,Ju Guangdong. Detection and safety evaluation of dilapidated brake buildings[J]. Yangtze River, 2001, 32(6):46-48.

[3] Wang Hangzhou.Detection, evaluation and maintenance of lock and hydraulic structures[J]. China Water Transport, 2010, 10(5):195-197

[4] Qi Jiehui, Chen Qingjun. Research for the reliability of the concrete bridge[J]. Science and Technology Consulting Herald, 2012(2):104-104.

[5] Liu Yutong. Measurement and evaluation of reinforced concrete structures[J]. Shanxi Architecture, 2014, 40(13):59-60.

[6] Wang Zhongjie, Lin Min.Safety assessment on the construction of concrete structures based on the reliability[J]. Industrial Safety and Environmental Protection, 2011, 37(6):46-47.

[7] Zhang Lu, Shi Yanghang. Reliability analysis method of the durability of concrete structures on active duty[J]. Low Temperature Architecture Technology, 2010, 32(9):30-32. 